\title{
Antioxidant Activity of a Cissus verticillata Fraction and Tyramine, its Bioactive Constituent, on Alloxan-Induced Diabetic Rats
}

\author{
Cleide de Sousa Lino ${ }^{1}$, Thiago de Paiva Sales ${ }^{1}$, Francisco S. Oliveira Alexandre ${ }^{2}$, Jamile M. Ferreira ${ }^{3}$, \\ Daniel Freire de Sousa ${ }^{3}$, Patrícia Bezerra Gomes ${ }^{1}$, Jeferson Falcão do Amaral ${ }^{1}$, Flávio D. Maia ${ }^{1}$, \\ Edilberto R. Silveira ${ }^{2}$, Maria Goreti Rodrigues de Queiroz ${ }^{3}$, Francisca Cléa Florenço de Sousa ${ }^{1}$ \\ and Glauce Socorro de Barros Viana*,1
}

\begin{abstract}
${ }^{I}$ Department of Physiology and Pharmacology, ${ }^{2}$ Department of Organic and Inorganic Chemistry, and ${ }^{3}$ Department of Clinical and Toxicological Analyses, Federal University of Ceará, Rua Coronel Nunes de Melo 1127, CEP 60430-270, Fortaleza, Brazil
\end{abstract}

\begin{abstract}
In the present study, the antioxidant activity of a methanol soluble fraction (MSF) from Cissus verticillata, used in Brazil and elsewhere as a hypoglycemic and antidiabetic medicinal plant, and tyramine (TYR), one of its main bioactive constituents, was assessed. For this, male Wistar rats were submitted to alloxan injection ( $40 \mathrm{mg} / \mathrm{kg}$, i.v.) in order to induce a diabetic state and, $48 \mathrm{~h}$ later, glycemia was determined. Animals were distributed into groups: normal controls (NC); diabetic controls (DC); DC plus MSF; and DC plus TYR. Another group was treated with glibenclamide (GLI), used as a positive control. After 5-day treatments, animals were sacrificed for liver dissection, and determination of antioxidant markers such as thiobarbituric acid reactive substances (TBARS), reduced glutathione (GSH), catalase and nitrite concentrations. The antioxidant effect was also evaluated on the pentobarbital-induced sleeping time, before and after $\mathrm{CCl}_{4}$ treatment. Under our experimental conditions, diabetic rats did not present any alteration in liver lipid peroxidation, before (DC) or after treatments with the MSF; TYR or GLI, as compared to normal controls (NC). Levels of GSH were significantly increased in $79 \%$ in DC, as related to $\mathrm{NC}$, and the effects were partially reversed in diabetic rats, after MSF treatments at the higher dose. However, while similar effects were observed after TYR and GLI, both drugs brought values of GSH to normality. The DC group had increased liver catalase activity, as compared to NC, and these effects were partially reversed by MSF and almost completely by TYR and GLI. Significant increases were also detected in nitrite concentrations in livers of DC, as an index of free radical formation, and a large reduction was observed after MSF, TYR and GLI treatments of diabetic rats, as compared to NC. MSF and TYR also prevented prolongation of the pentobarbitalinduced sleeping time by $\mathrm{CCl}_{4}$, suggesting hepatoprotective and anti-oxidative effects. In conclusion, we showed that the antioxidant activity probably plays an important role in the antidiabetic effect of $C$. verticillata, and TYR is at least in part responsible for this property.
\end{abstract}

Keywords: Cissus verticillata, hypoglycemic activity, free radicals formation, antioxidant activity.

\section{INTRODUCTION}

Diabetes is associated with a significant oxidative stress, and this oxidative damage may contribute to several diabetic complications [1]. Reactive oxygen species are known to be an important part of the defense mechanisms against infection, but excessive generation of free radicals or unsaturated fatty acids have been implicated in the pathogenesis of vascular diseases [2]. Diabetic patients have an increased incidence of vascular diseases, and it has been shown that free radical activity is elevated during diabetes [3]. In addition, free radicals seem to be responsible for the development of diabetic macroangiopathy as well as microangiopathy [4]. Previous studies $[5,6]$ demonstrated that increased freeradical reactions in patients with DM type II were responsible for the development of vascular changes. As a matter of fact, oxygen-derived free radicals have been suggested to

*Address correspondence to this author at the Department of Physiology and Pharmacology, Federal University of Ceará, Rua Barbosa de Freitas, 130/1 100, 60.170-020, Fortaleza, Brazil; Tel: 5585 3242-3064;

E-mail: osorio@ roadnet.com.br induce malfunction of endothelial cells, leading to diabetic angiopathy [7], and the development of vascular complications in diabetes correlates with the intensity of hyperglycemia [8].

It has been shown that cells adapt to oxidative stress conditions but, under hyperglycemic conditions, progressive glycosylation of the enzymatic proteins leads to decreases in their activities [9]. Diabetes mellitus (DM) is characterized by hyperglycemia together with biochemical alterations of glucose and lipid peroxidation [10]. Thus, some complications of DM are associated with the increased activity of free radical-induced lipid peroxidation and accumulation of lipid peroxidation products [11].

Low levels of Vitamin E are associated with increased incidence of diabetes, and some reports suggest that people with diabetes have decreased levels of antioxidants $[12,13]$. Another study [14] suggested that diabetes altered the metabolic state of oxidation-reduction type reactions, pointing out to a potential benefit of therapeutic intervention with antioxidants. The loss of antioxidant capacity is statistically associated with accelerated aging processes in diabetic pa- 
tients, due to an increase in basal oxidation products of erythrocytes associated with monosaccharide autooxidative glycation $[15,16]$.

Cissus verticillata (syn. C. sicyoides, Vitaceae) is a medicinal plant popularly known in Brazil as "cipó-pucá, aniltrepador, and cortina". Leaves decoction from $C$. verticillata called elsewhere as princess wine is widely taken as a popular remedy for diabetes in Brazil, where it is also known as "insulina vegetal". Several substances were isolated from $C$. verticillata. Thus, one work reported the presence in this species of tannins, steroid-triterpenes, amino acids, lipids and flavonoids [17], when the phytochemical analysis of the plant showed the presence of alkaloids, triterpenes, steroids, flavonoids, tannins, saponins and coumarins, among others $[18,19]$. Recently [20], tyramine was also for the first time isolated from the plant.

Some studies $[21,22]$ have shown that tyramine administration to diabetic rats increases glucose disposal and reduces hyperglycemia. We also demonstrated [23] antidiabetic and hypolypemic actions of the aqueous extract of the plant, as well as with tyramine, known to be present in this species [24]. Thus, the objectives of the present work was to further explore our previous data, by focusing now on possible antioxidant effects of a $C$. verticillata fraction, as well as of tyramine, one of its active constituents, in the model of alloxan-induced diabetes in rats.

\section{METHODS}

Animals. Male Wistar rats (180-200 g) from the Animal House of the Federal University of Ceará, Brazil, were used. Animals were maintained at standard conditions $\left(21-23^{\circ} \mathrm{C}\right)$, controlled humidity, $12 \mathrm{~h}$ light/dark cycle, with water and food ad libitum. Experiments were conducted according to the Guide for Care and Use of Laboratory Animals from the NIH, USA.

Plant and fractions isolation procedures. Fresh leaves of $C$. verticillata were harvested from the Prof. F.J.A. Matos Medicinal Plants Garden, at the Federal University of Ceará, Brazil. Voucher specimens (No. 32240), identified at Kew Garden, UK, are deposited at the Prisco Bezerra Herbarium at the same University.

Methanol Soluble Fraction Preparation (MSF). A three hundred gram aliquot of fresh leaves from Cissus verticillata was submitted (twice) to decoction with $500 \mathrm{~mL}$ of $\mathrm{H}_{2} \mathrm{O}$, for $5 \mathrm{~min}$. The procedure was repeated three more times, to yield a $4 \mathrm{~L}$ solution, from a total of $1.2 \mathrm{~kg}$ of leaves. After lyophilization, $29.5 \mathrm{~g}$ of a light brown solid residue was obtained, which in turn was stirred for $30 \mathrm{~min}$ (twice) with $50 \mathrm{~mL}$ of methanol, to afford $15.67 \mathrm{~g}$ of a viscous brown residue, after methanol rotoevaporation (MSF), and $11.35 \mathrm{~g}$ of the methanol insoluble residue (MIR). Among all the fractions tested for antidiabetic activity, the most active one was the MSF and, for this reason, it was chosen for further analyses [20].

Isolation of tyramine (present in $C$. verticillata leaves) from the MSF. MSF (5.1 g) was dissolved in MeOH and submitted to gel permeation over Sephadex LH-20 (100 g), on a $500 \mathrm{~mL}$ glass column $(5 \mathrm{~cm}$ diameter), by elution with $\mathrm{MeOH}$. This step resulted in 24 fractions ( $9 \mathrm{~mL}$ each), followed by two larger fractions (125 and $250 \mathrm{~mL})$, and finally by a $500 \mathrm{~mL}$ fraction eluted with $\mathrm{MeOH} / \mathrm{H}_{2} \mathrm{O} 1: 1$. After TLC comparison, three major fractions were obtained by pooling the similar fractions: $\mathrm{CvMsF}_{8-12}(1.23 \mathrm{~g}), \mathrm{CvMsF}_{13-18}(1.54 \mathrm{~g})$ and $\mathrm{CvMsF}_{19-24}(1.01 \mathrm{~g})$ by ${ }^{1} \mathrm{H} \mathrm{NMR}$ (500 MHz, MeOD). Analysis of all major fractions revealed the presence of a major compound in $\mathrm{F}_{19-24}$ that was later designated tyramine rich fraction (TRF). Besides the tyramine characteristic pair of doublets in the aromatic region (6.77 and $7.10 \mathrm{ppm}, \mathrm{J} 8.4$ $\mathrm{Hz}$ ) and the pair of triplets in the aliphatic region (2.87 and $3.12 \mathrm{ppm}$ ), several signals between 3.3 and $4.3 \mathrm{ppm}$, followed by doublets at 4.5 and $5.1 \mathrm{ppm}$, were indicative of the presence of sugar components. TRF was rechromatographed on Sephadex LH-20 by elution with $\mathrm{MeOH}$, to yield 12 fractions ( $9 \mathrm{ml}$ each) that were compared by TLC and pooled by similarity. $\mathrm{F}_{6-8}(750 \mathrm{mg})$ was redissolved in $\mathrm{MeOH}$ and, then, EtOAc was added dropwise until the formation of a light yellow precipitate. Filtration afforded $390 \mathrm{mg}$ of tyramine, after TLC co-cromatography and ${ }^{1} \mathrm{H}$ and ${ }^{13} \mathrm{C}$ NMR spectral analyses (157.8, 116.9, 130.9, 128.6, 42.4 and 33.9 ppm). These methods were performed either separately with tyramine from TRF and standard tyramine, or in a 1:1 mixture. The process was repeated 4 times, in order to provide enough material for all pharmacological assays [20]. For technical reasons (low yield) the standard tyramine used in the present study was purchased from Sigma Chem. Co. (Mo, USA). Drugs were dissolved in distilled water before use.

Procedure for determination of the antioxidant activity. After 5 days of oral (intragastric gavage) treatments, animals were killed by cervical dislocation. Then, the liver was immediately dissected and homogenized in $1.15 \% \mathrm{KCl}$, at a volume equivalent to 10 times its weight $(1 \mathrm{~g} / 10 \mathrm{ml}$ solution). The mixture was centrifuged $(5,800 \mathrm{rpm}, 10 \mathrm{~min}$ at $10^{\circ} \mathrm{C}$ ), and the supernatant used for biochemical determinations (TBARS, GSH, catalase, and nitrite).

Determination of lipid peroxidation levels in liver tissue. To $10 \%$ liver homogenates $(0.5 \mathrm{~mL})$ prepared in $1.15 \% \mathrm{KCL}$, were added $0.9 \mathrm{~mL}$ of sodium phosphate buffer $(50 \mathrm{mM}, \mathrm{pH} 7.4)$ and $0.5 \mathrm{~mL}$ of the free radicals formation catalyzing medium, containing FeSO4 $(0.01 \mathrm{mM})$ and ascorbic acid $(0.1 \mathrm{mM})$. The mixture was maintained for $30 \mathrm{~min}$ at $37^{\circ} \mathrm{C}$ when the reaction was stopped by the addition of 1 $\mathrm{mL}$ of $10 \%$ trichloroacetic acid, TCA. Then, after centrifugation (3,000 rpm, $15 \mathrm{~min}), 1 \mathrm{ml}$ of $0.8 \%$ thiobarbituric acid was added to the supernatant. The mixture was maintained in boiling water for $15 \mathrm{~min}$. After cooling, the thiobarbituric acid reactive substances (TBARS) concentration was measured spectrophotometrically at $532 \mathrm{~nm}$. Results expressed as $\mathrm{nmol} / \mathrm{mg} /$ protein were calculated from a standard MDA curve, which is a by-product of the lipid peroxidation reaction [25].

Reduced glutathione (GSH) and sulphydryl group determinations. GSH (L- $\gamma$-Glutamyl-L-cisteinyl-glycine) contains the most abundant intracellular thiol (-SH) groups, and constitutes an important antioxidant system in the cell [26]. The GSH concentration was determined by a modified Ellman (1959) method [27]. Briefly, to a $10 \%$ liver homogenate $(400 \mathrm{uL})$ prepared in $10 \%$ EDTA $(0.02 \mathrm{M})$, were added $320 \mu \mathrm{L}$ and $80 \mu \mathrm{L}$ of a $50 \%$ TCA solution. After centrifugation, $3,000 \mathrm{rpm}$, for $15 \mathrm{~min}$ at $4^{\circ} \mathrm{C}, 800 \mu \mathrm{L}$ of a 0.4 
M Tris- $\mathrm{HCl}(\mathrm{pH} 8.9)$ were added to a $400 \mu \mathrm{L}$ supernatant sample, followed by the addition of $20 \mu \mathrm{L}$ of $0.01 \mathrm{M}$ dithionitrobenzoic acid (DTNB). GSH concentration was spectrophotometrically determined at $420 \mathrm{~nm}, 1 \mathrm{~min}$ after the DTNB addition. Results were calculated from a standard GSH curve and expressed as $\mu \mathrm{g} / \mathrm{g}$ tissue.

Determination of catalase activity in the liver. Liver tissue was homogenized in a $0.1 \mathrm{M}$ sodium phosphate buffer solution, $\mathrm{pH} 7.0$, at an equivalent volume of 200 times its weight. Then, the homogenate was centrifuged at $5,800 \mathrm{rpm}$, $10 \mathrm{~min}$ at $4^{\circ} \mathrm{C}$, the upper layer was discarded and the bottom layer was used for spectrophotometric measurements at 230 $\mathrm{nm}$ [28]. In the cuvette, were added $980 \mu \mathrm{L}$ of the reaction medium $\left(15 \% \mathrm{H}_{2} \mathrm{O}_{2}\right.$, in $1 \mathrm{M}$ Tris-HCL buffer), containing 5 mM EDTA, pH 8.0, and $20 \mu \mathrm{L}$ of the sample diluted in the Tris- $\mathrm{HCl}$ buffer. Initial and final absorbances were recorded at $230 \mathrm{~nm}$, after 1 and $6 \mathrm{~min}$, respectively. A standard curve was established using purified catalase (Sigma, MO, USA). Results were expressed in $\mathrm{nmol} / \mathrm{min} / \mathrm{mg}$ protein. Protein was determined by the Lowry method [29].

Determination of the nitrite concentration. The Griess reagent $(0.1 \% \mathrm{~N}$-(1-naphthyl) ethylenediamine dihydrochoride in distilled water and $1 \%$ sulfanilamide in $5 \%$ phosphoric acid) is widely used to detect the presence of nitrite in samples of urine, plasma and tissues. The diazotization reaction forms a pink chromophore presenting a peak of absorption at $560 \mathrm{~nm}$. The $10 \%$ liver homogenate prepared in saline was centrifuged at 3,000 for $10 \mathrm{~min}$, and $100 \mu 1$ of the Griess reagent were added to $100 \mu 1$ of supernatant. The reaction mixture was incubated for $10 \mathrm{~min}$ at room temperature. For blanks, $100 \mu \mathrm{l}$ of the Griess reagent and $100 \mu \mathrm{L}$ of saline were used. The absorbance was measured at $560 \mathrm{~nm}$ in a microplate reader and the nitrite concentration was determined from a standard $\mathrm{NaNO}_{2}$ curve [30].

Barbiturate-induced sleeping time. Five groups (9-14 animals each) of male Swiss mice (25-35 g) were treated with the MSF (50 and $100 \mathrm{mg} / \mathrm{kg}$, p.o.) and TYR (1 and 2 $\mathrm{mg} / \mathrm{kg}$, p.o.). Controls were treated with vehicle (distilled water, $10 \mathrm{ml} / \mathrm{kg}$, p.o.). After $1 \mathrm{~h}$ treatments, animals were injected with sodium pentobarbital (40 mg/kg, i.p.), according to Dandiya and Collumbine, 1959 [31]. Animals were then evaluated for the sleep latency and duration of sleep.

Effect of $\mathbf{C C l}_{4}$ on the barbiturate-induced sleeping time. Five groups (6-9 animals each) of male Swiss mice $(25-35 \mathrm{~g})$ were treated with the MSF $(50$ and $100 \mathrm{mg} / \mathrm{kg}$, p.o.) and TYR (1 and $2 \mathrm{mg} / \mathrm{kg}$, p.o.). Controls were treated with the vehicle (distilled water, $10 \mathrm{ml} / \mathrm{kg}$ ). After $1 \mathrm{~h}$ treatments, animals were injected with $20 \% \mathrm{CCl}_{4}$ in olive oil (1 $\mathrm{ml} / \mathrm{kg}$, s.c.), according to Montila et al., 1990 [32]. Twenty four hours after $\mathrm{CCl}_{4}$ administration, the animals were treated with sodium pentobarbital, and evaluated for the sleep latency and duration of sleep.

\section{RESULTS}

Evaluation of the antioxidant activity of the methanol soluble fraction (MSF), tyramine (TYR), and glibenclamide (GLI) in aloxan-induced diabetic rats. Since in previous studies we showed no alteration in serum hepatic transaminases from alloxan-induced diabetic rats after treatment with MSF or TYR, we decided to investigate the alloxan-induced hepatotoxicity, in the absence and presence of
MSF and TYR, by measuring the levels of lipid peroxidation, enzymatic (catalase) and nonenzymatic (GSH) antioxidant systems, as well as nitrite concentration.

Determination of effects of MSF, TYR and GLI, on the rat liver lipid peroxidation. In Fig. (1), we present the effects of MSF, TYR and GLI on the formation of thiobarbituric acid reactive substances (TBARS), a parameter used to measure the aloxan-induced lipoperoxidation. Results showed that alloxan, at the dose of $40 \mathrm{mg} / \mathrm{kg}$, i.v., did not alter TBARS concentration in diabetic control rats (DC), as compared to normal controls (NC) treated with distilled water only. Similarly, diabetic animals treated with MSF (50 and $100 \mathrm{mg} / \mathrm{kg}$ ), TYR ( 1 and $2 \mathrm{mg} / \mathrm{kg}$ ) or GLI $(5 \mathrm{mg} / \mathrm{kg}$ ), orally for 5 days, did not significantly alter TBARS levels in the liver.

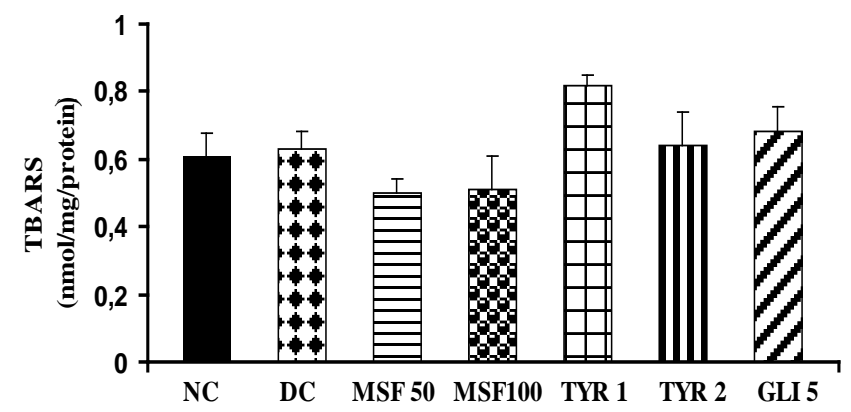

Fig. (1). Effects of MSF from Cissus verticillata, tyramine (TYR) and glibenclamide (GLI) on the activity of thiobarbituric reactive substances (TBARS), in the liver of diabetic rats. Diabetic rats were treated with distilled water (DC) or MSF (50 and $100 \mathrm{mg} / \mathrm{kg}$ ), TYR ( 1 and $2 \mathrm{mg} / \mathrm{kg}$ ), GLI ( $5 \mathrm{mg} / \mathrm{kg}$ ), orally for 5 days, and after treatments livers were dissected and homogenized. Values represent mean \pm SEM from 6 to 11 animals.

Determination of effects of MSF, TYR and GLI, on catalase activity in the rat liver. Fig. (2) shows that the catalase activity ( $\mathrm{mmol} / \mathrm{min} / \mathrm{mg}$ protein) in livers of the NC group $(0.13 \pm 0.019)$ was significantly increased, as related to the DC group $(0.29 \pm 0.044)$. However, the animals treatment with MSF for 5 days significantly inhibited the enzyme activity. Thus, at the lower dose, MSF $(50 \mathrm{mg} / \mathrm{kg}$, p.o.) reduced in $45 \%$ the catalase activity $(0.16 \pm 0.018)$, as compared to DC. There was no dose effect relationship, since at the higher dose $(100 \mathrm{mg} / \mathrm{kg}$, p.o. $)$ the effect was lower, corresponding to a $31 \%$ reduction of enzyme activity $(0.21 \pm$ 0.028 ) and suggesting that, at this dose range, MSF was already presenting its maximal effect.

Determination of effects of MSF, TYR or GLI, on reduced gluthatione levels in the rat liver. Fig. (3A) shows the effect of MSF on reduced glutathione (GSH) levels induced by alloxan, in rat livers. The liver GSH concentrations $(\mu \mathrm{g} / \mathrm{mg}$ tissue) decreased from $528.9 \pm 64.3$, in normal controls (NC) treated with distilled water only, to $111.2 \pm 17.1$, in diabetic controls (DC) treated with distilled water plus alloxan. The treatment of diabetic animals for 5 days with MSF (50 e $100 \mathrm{mg} / \mathrm{kg}$, p.o.) significantly increased hepatic GSH levels to $584.8 \pm 83.0$ and $350.6 \pm 57.6$, respectively. In Fig. (3B), the liver GSH concentrations $(\mu \mathrm{g} / \mathrm{mg}$ tissue) decreased from $122.0 \pm 24.6$ in the NC group to $17.1 \pm 2.8$ in the DC group. The treatment of diabetic animals with TYR (1 e $2 \mathrm{mg} / \mathrm{kg}$, p.o.) or GLI (5 mg/kg, p.o.) brought GSH 
levels to normal values (TYR 1: $121.9 \pm 23.9$; TYR 2: 112.3 \pm 15.3; GLI 5: $92.1 \pm 6.2$ ).

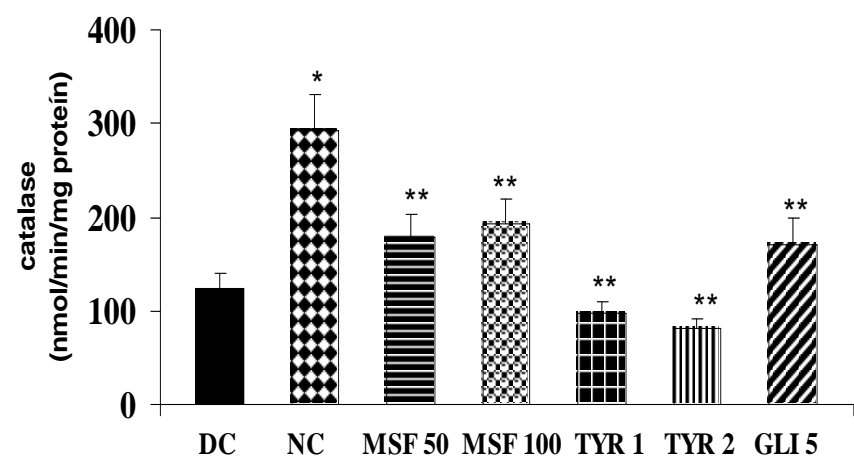

Fig. (2). Effects of MSF from Cissus verticillata, TYR and GLI on the activity of catalase, in the liver of diabetic rats. Diabetic rats were treated with distilled water (DC) or MSF (50 and $100 \mathrm{mg} / \mathrm{kg}$ ), TYR ( 1 and $2 \mathrm{mg} / \mathrm{kg}$ ), GLI ( $5 \mathrm{mg} / \mathrm{kg}$ ), orally for 5 days, and after treatments livers were dissected, homogenized and processed for catalase activity, as described in Material and Methods. Values represent mean \pm SEM from 5 to 10 animals. ${ }^{*} \mathrm{p}<0.05$, as compared to NC; $* * \mathrm{p}<0.05$, as compared to DC (ANOVA and Student-Newman-Keuls as the post hoc test).

A

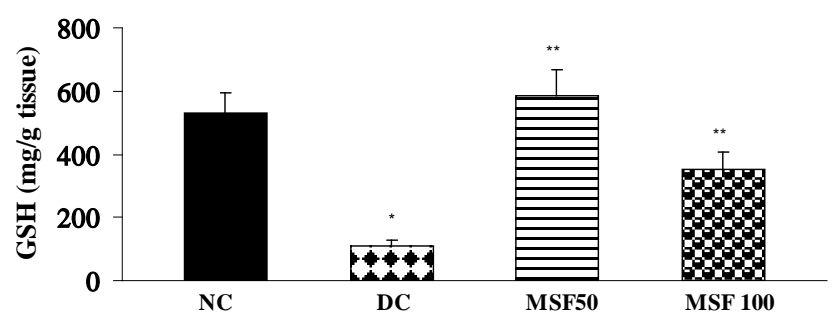

B

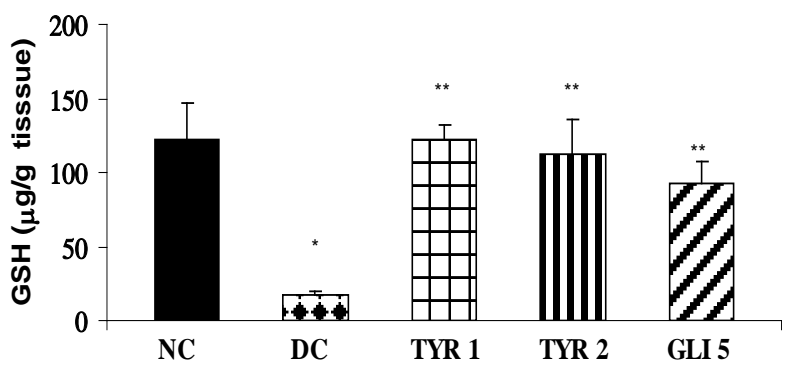

Fig. (3). Effects of the methanol soluble fraction (MSF) from Cissus verticillata (A), tyramine (TYR) and glibenclamide GLI) (B) on the activity of reduced glutathione (GSH), in the liver of diabetic rats. Diabetic rats were treated with distilled water (DC) MSF (50 and $100 \mathrm{mg} / \mathrm{kg}$ ), TYR (1 and $2 \mathrm{mg} / \mathrm{kg}$ ), or GLI (5 mg/kg), orally for 5 days, and after treatments livers were dissected and homogenized and the GSH content was estimated according to Material and Methods. Values represent mean \pm SEM of 5 to 11 animals. ${ }^{*} \mathrm{p}<$ 0.05 , as compared to $\mathrm{NC} ; * * \mathrm{p}<0.05$, as compared to $\mathrm{DC}$ (ANOVA and Student-Newman-Keuls as the post hoc test).

Determination of MSF, TYR and GLI, on nitrite levels in the rat liver. Fig. (4) shows a significant increase in nitrite levels $(\mu \mathrm{M})$ in livers of DC rats $(14.7 \pm 2.06)$, as com- pared to NC (1.6 \pm 0.34$)$. However, MSF (50 and 100 $\mathrm{mg} / \mathrm{kg}$, p.o.) reduced nitrite levels in $65 \%(5.1 \pm 1.51)$ and $68 \%(4.7 \pm 1.18)$, respectively. A similar picture was observed after the treatment of diabetic rats with TYR ( 1 and 2 $\mathrm{mg} / \mathrm{kg}$, p.o.) that reduced nitrite levels in $79(3.0 \pm 1.46)$ and $82 \%$ (3.2 \pm 1.14$)$. Similar data were observed after GLI treatment of diabetic rats, showing a $78 \%$ decrease in nitrite levels, as compared to NC $(3.2 \pm 1.81)$.

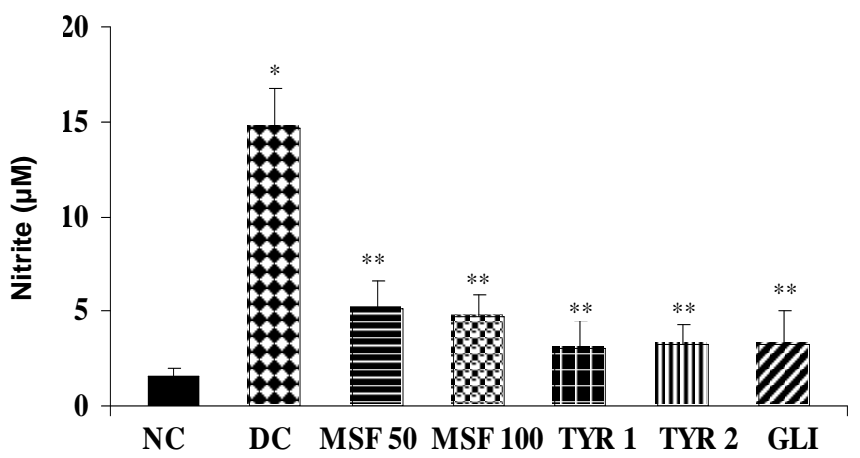

Fig. (4). Effects of the methanol soluble fraction (MSF) from Cissus verticillata, tyramine (TYR) and glibenclamide (GLI) on the reduction of nitrite levels, in the liver of diabetic rats. Diabetic rats were treated with distilled water (DC) or MSF (50 and $100 \mathrm{mg} / \mathrm{kg}$ ), TYR ( 1 and $2 \mathrm{mg} / \mathrm{kg}$ ), GLI ( $5 \mathrm{mg} / \mathrm{kg}$ ), orally for 5 days, and after treatments livers were dissected, homogenized and processed for nitrite determination according to Material and Methods. Values represent mean \pm SEM from 4 to 6 animals. ${ }^{*} p<0.05$, as compared to NC; $* * \mathrm{p}<0.05$, as compared to DC (ANOVA and StudentNewman-Keuls as the post hoc test).

Determination of effects of MSF and TYR on the pentobarbital-induced sleeping time, in the absence and presence of $\mathbf{C C l}_{4}$ treatment, in rats. Tables $\mathbf{1}$ and $\mathbf{2}$ show that, while sleeping latency was unaltered by MSF it was increased by 55 and $36 \%$, by TYR (1 and $2 \mathrm{mg} / \mathrm{kg}$, p.o.), respectively. However, neither MSF nor TYR affected sleep duration. In the presence of $\mathrm{CCl}_{4}$, a significant prolongation $(57 \%)$ of the pentobarbital-induced sleeping time was observed, and the lower dose of MSF was unable to block that effect. However, MSF at the higher dose, as well as TYR at both doses, completely reversed the $\mathrm{CCl}_{4}$ prolongation of the pentobarbital-induced sleeping time, and values were close to those demonstrated in the absence of $\mathrm{CCl}_{4}$ administration.

Table 1. Effects of the Methanol Soluble Fraction (MSF) from Cissus verticillata (MSF) and Tyramine (TYR) on the Pentobarbital-Induced Sleeping Time, in Mice

\begin{tabular}{|c|c|c|}
\hline Group (mg/kg, p.o) & Sleep latency (s) & Sleep Duration (min) \\
\hline \hline Control & $233 \pm 16.8(9)$ & $60 \pm 4.7$ \\
\hline MSF 50 & $198 \pm 9.2(10)$ & $59 \pm 6.1$ \\
\hline MSF 100 & $227 \pm 10.2(10)$ & $50 \pm 5.4$ \\
\hline TYR 1 & $516 \pm 55.3(10)^{\mathrm{a}}$ & $59 \pm 7.5$ \\
\hline TYR 2 & $364 \pm 39.5(14)^{\mathrm{a}}$ & $48.3 \pm 7.4$ \\
\hline
\end{tabular}

Animals were treated with the MSF (50 e $100 \mathrm{mg} / \mathrm{kg}$ ), TYR (1 e $2 \mathrm{mg} / \mathrm{kg}$ ), and after 1 $\mathrm{h}$ they were injected with pentobarbital $(40 \mathrm{mg} / \mathrm{kg}$, i.p.) when the parameters studied (sleep latency and sleep duration) were evaluated. Values are means \pm SEM of the number of animals in parentheses. ${ }^{\mathrm{a}} \mathrm{p}<0.05$, as related to controls (ANOVA and Student-Newman-Keuls as the post hoc test). 
Table 2. Effect of the Methanol Soluble Fraction (MSF) from Cissus verticillata and Tyramine (TYR) on the Prolongation of the Pentobarbital-Induced Sleeping Time by $\mathrm{CCl}_{4}$ in Mice

\begin{tabular}{|c|c|c|}
\hline Group (mg/kg, p.o) & Sleep Latency (s) & Sleep Duration (min) \\
\hline \hline Control & $261 \pm 23.0(9)$ & $127 \pm 11.9$ \\
\hline MSF 50 & $277 \pm 31.3(7)$ & $114 \pm 14.1$ \\
\hline MSF 100 & $340 \pm 36.0(7)$ & $41 \pm 6.6^{\mathrm{a}}$ \\
\hline TYR 1 & $276 \pm 33.5(6)$ & $44 \pm 3.5^{\mathrm{a}}$ \\
\hline TYR 2 & $382 \pm 37.5(6)^{\mathrm{a}}$ & $37 \pm 4.42^{\mathrm{a}}$ \\
\hline
\end{tabular}

Animals were treated with MSF (50 e $100 \mathrm{mg} / \mathrm{kg}$ ), TYR (1 e $2 \mathrm{mg} / \mathrm{kg}$ ), followed by $20 \% \mathrm{CCL}_{4}(1 \mathrm{ml} / \mathrm{kg}$, s.c. $), 1 \mathrm{~h}$ later. Twenty four hours after the $\mathrm{CCl}_{4}$ injection, animals were administered with pentobarbital $(40 \mathrm{mg} / \mathrm{kg}$, i.p.) and evaluated for sleep latency and sleep duration. Values represent means \pm SEM of the number of animals in parentheses. ${ }^{\mathrm{a}} \mathrm{p}<0.05$, as related to controls (ANOVA and Student-Newman-Keuls as the post hoc test).

\section{DISCUSSION}

Diabetes mellitus is characterized by hyperglycemia together with biochemical alterations of glucose and lipid peroxidation [10]. Lipid peroxidation is a free radical-related process, involved in oxidative stress which plays a major role in the pathogenesis of diabetes mellitus [33]. Abnormally high levels of lipid peroxidation and the simultaneous decline of antioxidant defense mechanisms can lead to damage of cellular organelles and subsequent oxidative stress.

Alloxan induces "chemical diabetes" in a wide variety of animal species, by damaging the insulin secreting pancreatic beta cells, at doses ranging from 40 to $200 \mathrm{mg} / \mathrm{kg}$, (i.v. or i.p.). Although it is largely accepted that alloxan at higher doses is a model of type 1 diabetes, at a lower dose, such as that used in the present study $(40 \mathrm{mg} / \mathrm{kg}$, i.v.), it produces a type 2 diabetes, because of a residual insulin secretion [34]. Hyperglycemia increases the generation of free radicals which may lead to liver cells damage, and the increase of oxygen free radicals in diabetes could be primarily due to the increase in blood glucose levels and secondarily to the effects of alloxan [35].

In a previous work [23], we showed that the daily treatment of diabetic rats with the aqueous extract from $C$. verticillata (AECS) for 7 days (100 and $200 \mathrm{mg} / \mathrm{kg}$, p.o.) significantly decreased blood glucose levels in 25 and $22 \%$, respectively, as compared to the same groups before AECS treatment. While no changes were seen in total cholesterol levels, a significant decrease was observed in plasma triglyceride levels, in the alloxan-induced diabetic rats after AECS treatment with both doses, as compared to the same groups before treatment.

These results agree with recent ones [24] where we showed significant hypoglycemic and hypolipemic effects of the methanol soluble fraction (MSF) and tyramine (TYR), its main bioactive constituent, in the model of alloxan-induced diabetes in rats. MSF and TYR were also active in decreasing hepatic glycogen and glycosylated hemoglobin as well. Furthermore, both drugs protected pancreatic beta cells from alloxan toxicity. In the present study, levels of hepatic lipid peroxidation, as measured by the formation of TBARS, were not significantly altered by alloxan. Similarly, in diabetic rats after treatment with MSF, TYR or glibenclamide, levels of TBARS were maintained unaltered, as compared to normal controls. Possibly, in our protocols, the low dose of alloxan (40 mg/kg, i.v.) leading to moderate levels of blood glucose was not sufficient to induce an increase in lipid peroxidation levels.

Abnormally high levels of lipid peroxidation and the simultaneous decline of antioxidant defense mechanisms can lead to damage of cellular organelles and subsequent oxidative stress. Recent findings indicate that the increase in the lipid peroxidation product, MDA, and the decline in glutathione-dependent antioxidant defenses may appear early in non-insulin dependent type 2 diabetes mellitus patients, before the development of secondary complications [36].

We also showed a significantly increased liver catalase activity in alloxan-induced diabetic rats, as compared to normal controls. The treatment of diabetic rats with MSF or TYR brought the enzyme activity to normal levels, and similar results were observed in the GLI treated diabetic rats. Similarly to our findings, a recent work [37] demonstrated that the catalase activity was significantly increased in the liver of alloxan-induced diabetic rabbits, and values were normalized by repaglinide, an oral antidiabetic drug. Furthermore, increased levels of catalase were observed in liver of alloxan-induced diabetic rats [38] what, according to Kakkar et al., 1995 [1], is due to the oxidative stress and increased production of hydrogen peroxide caused by diabetes.

Alloxan exerts its diabetogenic effect by the production of $\mathrm{H}_{2} \mathrm{O}_{2}$ in intact islets [39]. The liver contains high superoxide dismutase (SOD), catalase, and reduced glutathione (GSH) activities which can scavenge alloxan-induced free radicals. On the contrary, islet cells have low concentrations of these enzymes, making then vulnerable to cytotoxic effects of free radicals [2]. According to Malaise et al., 1982 [40], alloxan decreases the islet GSH content, as well as glucose oxidation and glucose-stimulated insulin release by pancreatic islets. These functional effects of alloxan are presumably relevant to the cytotoxic action of the drug. The activity of GSH peroxidase, an enzyme catalyzing the reduction of peroxides, was found to be much less in pancreatic islets than in other tissues [40]. These findings suggest that the selective cytotoxicity of alloxan to pancreatic beta cells result from a rapid cellular uptake of the drug and a great sensitivity to peroxide (low GSH peroxidase and catalase activities).

In the present study, levels of liver GSH decreased significantly in almost $80 \%$, in diabetic animals, as compared to normal controls. The treatment of diabetic animals with MSF reversed the alloxan effect, and values of GSH leveled up towards normality. A similar finding was demonstrated after TYR or GLI treatments. Sailaja et al., 2003 [41], reported that diabetic patients have shown increased lipid peroxidation and decreased levels of glutathione, glutathione reductase, glutathione peroxidase, glutathione, and glucose-6phosphate dehydrogenase.

Diabetic rats also showed increased MDA levels, whereas antioxidant enzymes such as reduced glutathione, SOD and glutathione peroxidase were markedly diminished, in comparison to controls [42-43]. Alloxan-induced diabetic 
rats presented an almost 10 times increase in nitrite levels, indicative of free radicals formation. A great reduction of TBARS levels was observed after treatment of diabetic animals with MSF, pointing out to a blockade caused by MSF in the alloxan-induced oxidative stress. The effect was even greater after treatment of diabetic animals with TYR, suggesting that $C$. verticillata has an important antioxidant activity.

It is known [44] that hyperglycemia induces an over production of oxygen radicals, and consequently increases protein and lipid oxidations in diabetic patients. These findings suggest that diabetes is an altered metabolic state of oxidation-reduction. Proteins and lipids are among the main targets for oxidative stress.

$\mathrm{CCl}_{4}$ treatment decreases SOD, catalase, glutathione and glutathione peroxidase, and increases lipid peroxidation. SOD is a ubiquitous cellular enzyme that dismutates superoxide radicals to $\mathrm{H}_{2} \mathrm{O}_{2}$ and oxygen, and is one of the main cellular defense mechanisms. The $\mathrm{H}_{2} \mathrm{O}_{2}$ formed by SOD and other processes is scavenged by catalase, an enzyme responsible for the dismutation of $\mathrm{H}_{2} \mathrm{O}_{2}$ into $\mathrm{H}_{2} \mathrm{O}$ and molecular oxygen. Glutathione is an important naturally occurring antioxidant, as it prevents hydrogen of the sulfhydryl group to be abstracted, instead of methylene hydrogen of unsaturated lipids. Therefore, levels of glutathione are of critical importance in tissue injury caused by toxic substances. The antioxidant enzymes and glutathione form the first line of defense against free radical-induced damage, offering protection against free radicals and thereby maintaining low levels of lipid peroxidase [45]. Peroxidase is an enzyme that catalyzes the reduction of hydroperoxides, including hydrogen peroxides, and functions in order to protect the cell from peroxidative damage.

It has been shown that the activation of amino oxidases, present in insulin-sensitive tissues, by tyramine induces insulin-like effects, and increases peripheral glucose utilization [21]. Tyramine stimulates glucose transport in rodent or human adipocytes through their oxidation by semicarbazidesensitive amino oxidase (SSAO) or monoamine oxidase (MAO) [46, 47]. Furthermore, the amine-dependent stimulation of glucose transport was found to be mediated by hydrogen peroxide, generated during amine oxidation, since it was prevented by catalase, glutathione or $\mathrm{N}$-acetylcysteine. In fact, hydrogen peroxide is an insulin mimicking agent that enhances glucose transport [48], stimulates lipogenesis [49] and inhibits lipolysis [50] in fat cells. These insulin-like effects seem to be mediated at least in part by tyrosine phosphorylation of intracellular proteins [51].

The sympathomimetic action of tyramine, leading to undesirable effects, talks against a possible therapeutic approach to diseases linked to glucose intolerance. However, other amines, such as benzylamine, devoid of sympathomimetic effects, like tyramine, also reduce the hyperglycemia of streptozotocin-induced diabetic rats [52]. Recently [53], tyramine and benzylamine were reported to mimic insulin action on adipose differentiation, and the stimulation of adipogenesis by these drugs was an SSAO-dependent mechanism that apparently shared common signaling pathways with insulin.
The antioxidant activity of $C$. verticillata demonstrated in the present study has been detected in extracts of other species of the genus Cissus, such as C. quadrangularis [54-56]. We assume that the antioxidant effects of MSF and tyramine on defense mechanism enzymes are, at least in part, responsible for the hypoglycemic activity of the plant as observed by us [24]. Furthermore, the effects of these drugs on the $\mathrm{CCl}_{4}$-treated rats were probably also due to their antioxidant activity, since $\mathrm{CCl}_{4}$-induced hepatotoxicity is a consequence of free radicals production [56]. In conclusion, not only the hypoglycemic but also the hypotriglyceridemic effects of $C$. verticillata are, in great part, due to the ability of this species to scavenger free radicals and to antagonize oxidativeinduced tissue damages as those seen in several pathologies, including diabetes.

\section{ACKNOWLEDGEMENTS}

Financial support for this study was provided by the Brazilian National Research Council (CNPq) and the Research Foundation for Science of the State of Ceará, Brazil (FUNCAP). We thank Prof. M.O.L. Viana for the orthographic revision of the manuscript.

\section{REFERENCES}

[1] Kakkar, R.; Kalra, J.; Mantha, S.V.; Prasad, K. Mol. Cell Biochem., 1995, 151, 113.

[2] Halliwell, B.; Gutteridge, J.M.C. Free Rad. Biol. Med., 1989, $2^{\text {nd }}$ Ed., Oxford: Clarendon Press.

[3] Oberley, L.W. Free Rad. Biol. Med., 1988, 5, 113.

[4] Barnett, A.H. Am. J. Med., 1991, 90 (Suppl. 6 A), 67.

[5] Collier, A.; Wilson, R.; Bradley, H.; Thomson, J.A.; Small, M. Diabetic Med., 1990, 7, 27.

[6] Sinclair, A.J.; Girling, A.J.; Gray, L. Gerontology, 1992, 38, 268.

[7] Ha, H.; Kim, K.H. Kidney Int. Suppl., 1995, 51, S18.

[8] Kedziora-Kornatowska, K.Z.; Luciak, M.; Blasszczyk, J.; Pawlak, W. Nephrol. Dial. Transplant., 1998, 13, 2829.

[9] Nishida, T.; Nakagawa, S.; Manabe, R. Jap. J. Ophtalmol., 1984, $28,377$.

[10] Pari, L.; Latha, M. Singapore Med. J., 2002, 43, 617.

[11] Palanduz, S.: Ademoglu, E.; Gokkusu, C., Tamer, S. Res. Commun. Mol. Pathol. Pharmacol., 2001, 109, 309.

[12] Quilliot, D.; Walters, E.; Bonte, J.P.; Fruchart, J.C.; Duriez, P.; Ziegler, O. Am. J. Clin. Nutr., 2005, 81, 1117.

[13] Ndahimana, J.; Dorchy, H.; Vertongen, E.C. Press Med., 1996, 25, 188 .

[14] Ramakrishna, V.; Jailkhani, R. Diagn. Pathol., 2007, 2, 22.

[15] Engler, M.M.; Engler, M.B.; Malloy, M.J.; Chiu, E.Y.; Schloetter, M.C.; Paul, S.M.; Stuehlinger, M.; Lin, K.Y.; Cooke, J.P.; Morrow, J.D.; Ridker, P.M.; Rifai, N.; Miller, E.; Witztum, J.L.; MietusSnyder, M. Circulation, 2003, 108, 1059.

[16] Tiwari, A.K. Curr. Sci., 2004, 86, 1092.

[17] Lizama, R.S.; Martinez, M.M.; Pérez, O.C. Rev. Cubana Farm., 2000, 34, 2000.

[18] Otshudi, A.L.; Foriers, A.; Vercruysse, A.; Van Zeebroeck, A.; Lauwers, S. Phytomed., 2000, 7, 167.

[19] Beltrame, F.L.; Sartoretto, J.L.; Bazotte, R.B.; Cuman, R.N.; Cortez, D.A.G. Química Nova, 2001, 24, 783.

[20] Alexandre, F.S.O. Dissertação de Mestrado em Química Orgânica, Universidade Federal do Ceará, Brazil, 2007, 206 p.

[21] Morin, N.; Visentin, V.; Calise, D.; Marti, L.; Zorzano, A.; Testar, X.; Valet, P.; Fisher, Y.; Carpene, C. J. Pharmacol. Exp. Ther., 2002, 303, 1238 .

[22] Visentin, V.; Prévot, D.; De Saint Front, V.D.; Morin-Cussac, N.; Thalamas, C.; Galitzky, J.; Valet, P.; Zorzano, A.; Carpéne, C. Obes. Res., 2004, 12, 547.

[23] Viana, G.S.B.; Medeiros, A.C.C.; Lacerda, A.M.R.; Leal, L.K.A.M.; Vale, T.G.; Matos, F.J.A. BMC Pharmacol., 2004, 4, 9.

[24] Lino, C.S.; Sales, T. P.; Alexandre, F.S.O.; Ferreira, J.M.; Sousa, D.F.; Gomes, P.B.; Amaral, J.F.; Maia, F.D.; Silveira, E.R.; Queiroz, M.G.R.; Sousa, F.C.F.; Viana, G.S.B. Am. J. Agric. Biol. Sci., 2008, (in press). 
[25] Huong, N.T.O.; Matsumoto, K.; Kasai, R.; Yamasaaki, K.; Watanabe, H. Biol. Pharm. Bull., 1998, 21, 978.

[26] Meister, A.; Anderson, M.E. Ann. Rev. Biochem., 1983, 52, 711.

[27] Ellman, G.L. Arch. Biochem. Biophys., 1959, 82, 70.

[28] Aebi, H. Methods Enzym. Anal., 1984, 2, 673.

[29] Lowry, O.H.; Rosebrouh, N.J.; Farr, A.L.; Randall R.J. J. Biol. Chem., 1951, 193, 40.

[30] Green, L.C.; Tannenbaum, S.R.; Goldman, P. Science, 1981, 212, 56.

[31] Dandiya, P.C.; Cullumbine, H. J. Pharmacol. Exp. Ther., 1959, $125,353$.

[32] Montilla, M.P.; Cabo, J.; Navarro, M.C.; Rico, S.; Jimenez, R.S.; Aneiros, J. Phytother. Res., 1990, 4, 212.

[33] Maritim, A.C.; Sanders, R.A.; Watkins, J.B., $3^{\text {rd }} . J$. Biochem. Mol. Toxicol., 2003, 17, 24.

[34] Srinivasan, K.; Ramarao, P. Ind. J. Med. Res., 2007, 125, 451.

[35] Szhudelski, T. Physiol. Res., 2001, 50, 537.

[36] Mahboob, M.; Rahman, M.F.; Grover, P. Singapore Med. J., 2005, 46, 322 .

[37] Gumieniczek, A. Acta Diabetologica, 2005, 42, 75-81.

[38] Mazzanti, C.M.; Schossler, D.R.; Filappi, A.; Prestes, D.; Balz, D.; Miron, V.; Morsch, A.; Schetinger, M.R.C.; Morsch, V.M.; Cecim, M. Ciência Rural, Santa Maria, 2003, 33, 1061.

[39] Drews, G.; Krämer, C.; Düfer, M.; Krippeit-Drews, P. Biochem. J., 2000, 352, 389.

[40] Malaisse, W.J.; Malaisse-Lagae, F.; Sener, A.; Pipeleers, D.G. Proc. Natl. Acad. Sci. USA, 1982, 79, 927.

[41] Sailaja, Y.R. Free Radic. Biol. Med., 2003, 35, 133.
[42] Kinalski, M.; Sledziewski, A.; Telejko, B.; Zarzycki, W.; Kinalski, I. Acta Diabetol., 2000, 37, 179.

[43] Ugochukwu, N.H.; Cobourne, M.K. Clin. Chim. Acta, 2003, 336, 73.

[44] Kono, Y. Arch. Biochem. Biophys., 1978, 86, 189.

[45] Enrique-Tarancon, G.; Castan, I.; Morin, N.; Marti, L.; Abella, A.; Camps, M.; Casamitjana, R.; Palancin, M.; Testar, X.; Degerman, E.; Carpéné, C.; Zorzano, A. Biochem. J., 2000, 350, 171.

[46] Morin, N.; Lizcano, J.M.; Fontana, E.; Marti, L.; Smih, F.; Rouet, P.; Prevot, D.; Zarzano, A.; Unzeta, M.; Carpené, C. J. Pharmacol. Exp. Ther., 2001, 297, 563.

[47] Taylor, W.M.; Halperin, M.L. Biochem. J., 1979, 178, 381.

[48] May, J.M.; de Haën, C. J.Biol. Chem., 1979, 254, 9017.

[49] Little, S.A.; De Haen, C. J. Biol. Chem., 1980, 255, 10888.

[50] Heffetz, D.; Bushkin, I.; Dror, R.; Zick, Y. J. Biol. Chem., 1990, 265, 2896.

[51] Marti, L.; Abella, A.; Carpene, C.; Palacin, M.; Testar, X.; Zorzano, A. Diabetes, 2001, 50, 2061.

[52] Subra, C.; Fontana, E.; Visentin, V.; Testar, X.; Carpéné, C. J. Physiol. Biochem., 2003, 59, 209.

[53] Chidambara-Murthy, K.N.; Vanitha, A.; Mahadeva-Swamy, M.; Ravishankar, G.A. J. Med. Food, 2003, 6, 99.

[54] Oben, J.E.; Enyegue, D.M.; Fomekong, G.I.; Soukontoua, Y.B.; Agbor, G.A. Lipids Health Dis., 2007, 6, 4.

[55] Jainu, M.; Vijai, M.K.; Shyamala, C.S. J. Ethnopharmacol., 2006, 104, 302.

[56] Jainu, M.; Shyamala, C.S. Afr. J. Biomed. Res., 2005, 8, 95. 